\title{
57
}

\section{CARACTERISATION D'ONCOGENES ACTIVES DANS LES TUMEURS DE XERODERMA PIGMENTOSUM.}

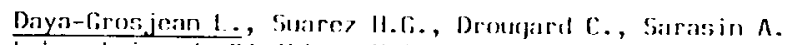

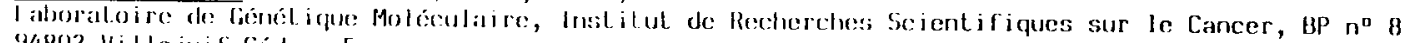
94802 Villojuif cedex, F rance.

Xeroderma pigmentosum (XP) est une maladie transmise de façon héréditaire, très complexe, qui se manifeste par une déficience dans la réparation de l'ADN. En effet, les malades (XP classiques) expriment une hypersensibilité aux irradiations ultraviolettes avec une prédisposition importante pour le développement des tumeurs de la peau. Le défaut dans l'incision des dimères de pyrimidine rend les cellules de XP hypermutables par des agents qui miment les U.V. Nous avons testé le pouvoir transformant de l'ADN de haut poids moléculaire isolé de deux tumeurs provenant d'un enfant XP. Par les techniques de transfert de gène dans les cellules 3T3 de souris, nous avons pu démontrer la présence d'un oncogène $\mathrm{N}$-ras activé. La méthode d'amplification génique in vitro suivie d'hybridation différentielle avec des oligonucléotides synthétiques montre que le codon 61 du gène $\mathrm{N}$-ras transformant a subi une mutation ponctuelle, ce qui fait coder pour l'histidine au lieu de la glutamine. Les techniques de "dot blot" et de Northern montrent que le gène est sur-exprimé dans les tumeurs et les clones transférants. L'immunoprécipitation du produit de l'oncogène, p21, montre l'existence d'une forme anormale dans un des transformants. Dans les mêmes tumeurs, nous avons identifié la présence d'un oncogène c-myc amplifié et sur-exprimé, ainsi que d'un oncogène Ha-ras remanié et sur-exprimé. La présence de plusieurs oncogènes modifiés dans la même tumeur peutêtre corrélée avec le grand nombre de lésions induites par les UV dans les cellules exposées au soleit.

\section{8}

\section{EPIDERMAL GROWTH FACTOR RECEPTOR AND RELATED GENES ALTERATIONS IN HUMAN BREAST METASTATIC CELLS}

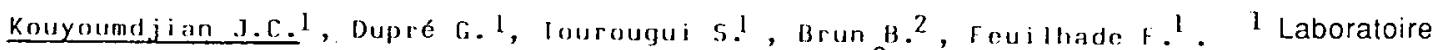
d'Oncologie Clinique et Fondamentale de l'Université Paris XII, 2 Département de cancerologie - Hôpital Henri Mondor 94010 CRETEIL Cedex FRANCE

The Epidermal Growth Factor receptor (EGF-r) is a glycoprotein of $170 \mathrm{KDa}$ molecular weight whose gene is frequently amplified in human malignancies. In human mammary carcinomas its expression is associated with poor prognosis disease and metastatic extension. The EGF-r gene structure exhibited a high degree of homology with two other related oncogenes : v-erb-B and c-erb-B2/neu. We have examined the EGF$r$ gene in human metastatic mammary carcinomas samples by Southern Blot analysis and compared to the patterns obtained with the two related genes probes. Different control specimens are analysed simultaneously. Our datas shown that 2 distinct types of modification are exhibited by metastatic cells : aberrant fragment size and sequencial amplification. In parallel the patterns obtained with the two oncogenes are compared. For some patients the duplicate alterations observed with 2 different genes are discussed.

Supported in part by a grant of the "Association de la Recherche sur le cancer" $n^{\circ} 6699$ and a grant from the "Université Paris XII" n¹017R1. 